\title{
Research on the Current Situation of "Chinese Cultural Aphasia" in Chinese College English Education
}

\author{
Li Zhaoying \\ Jilin Business and Technology College \\ Changchun City, China \\ 575970611@qq.com
}

\begin{abstract}
Keywords: Current Situation, "Chinese Cultural Aphasia", Chinese College, English Education
\end{abstract}
\begin{abstract}
In the case of continuous reform of our education system, English teaching has become an indispensable lesson in our education system. Learning English is to facilitate conversation with foreign friends, it is to be able to bring our excellent traditional culture into Western countries, so that Western countries will better understand China. This paper will analyze the phenomenon of "Chinese cultural aphasia" in English education in colleges and universities in our country, so as to put forward the relevant measures to solve this problem.
\end{abstract}

\section{Introduction}

With the deepening reform of English education system and teaching idea in our country, we have integrated some diversified teaching modes in the process of English teaching, and have enriched the students' learning ability under the leadership of the relevant education and teaching department. And in this process, college English teachers not only need to teach students the grammar of English, but also must be within the target language within the English culture and social background are taught to teach to students, which can effectively Improve students' intercultural language learning and communication. However, in the rest of the world, in the process of cross-cultural education and teaching, the integration of local culture in China is relatively small. And in the current educational model, cross-cultural teaching rarely in China's traditional culture as its carrier, so that most students learn English in cross-cultural communication as information, a serious study of English deviation, in the process of teaching English is called "Chinese culture aphasia." In the process of intercultural English teaching, the phenomenon of "Chinese cultural aphasia" leads to the lack of traditional culture in China, which restricts the development and development of Chinese traditional culture history and has a certain influence on cultivating high quality talents. Therefore, this article has carried on the thorough research to the present situation of "Chinese cultural aphasia", and has put forward the feasible suggestion, has the very vital role to promote the ecology development and the inheritance of the history and culture among the national peoples.

\section{The Research Background of "Chinese Cultural Aphasia"}

In the relevant teaching departments of our country, we have made a clear stipulation on the teaching and preparation of English majors in colleges and universities, and clearly stipulated the English courses of English in the College English syllabus of colleges and universities. The need to choose the relevant courses of Western culture as an elective course, but also must be set up with the Chinese culture-related professional courses, so that students can master more about the content of traditional Chinese culture, the purpose is to allow students in some foreign cultural and historical research and the process of learning to deepen our traditional culture of knowledge and consolidation. However, with the impact of the global economic sphere, the importance of English within the world is also increasing. "Cambridge English Language Encyclopedia" pointed out that the world has more than half of the country will be included in the language of English, and some international organizations have also been English as the world's common language, to a large 
extent promoted its development. With the continuous development and acceleration of political integration, the development trend and mode of "unipolarization" have appeared at the same time. At present, the research and practice of English teaching process in Chinese colleges and universities have just been in the stage of development. The process is still relatively weak, and cannot be their culture in English expressed making the "Chinese culture aphasia" phenomenon is more serious. In the strict sense, the traditional culture of China mainly includes different cultural backgrounds, customs and religious culture, especially the cultural, historical and geographical background of the Chinese nation. College English in the teaching process must first strengthen the traditional Chinese culture for the effective dissemination and promotion, and comprehensively improve the quality of education and teaching. Therefore, this paper analyzes the English teaching in colleges and universities by using the questionnaire and inquiry test, and puts forward the corresponding measures to improve the quality of English teaching in colleges and universities in our country, and promote and promote the excellent Chinese nationality Traditional cultural history.

\section{The Status Quo of "Chinese Cultural Aphasia"}

Intercultural communication is a two-way communication, learning and understanding of the process of culture, we must agree with the Chinese culture, the two are complementary. According to the relevant reference, it can be seen that some students of higher education can be very clear about some of their familiar things, but they have little knowledge of what they have never touched upon. This shows that in the process of English education, the emphasis on English culture too much attention, leading to the lack of inheritance of Chinese culture phenomenon, especially for the phenomenon of Chinese cultural aphasia.

Language as a carrier of culture, if the language of the language of the language also lost its own meaning, then it will lose the meaning of language. Therefore, learning English culture is not only the understanding and perception of language, but also to be able to better communicate. In the process of teaching in the university, the phenomenon of English culture shows that college students also lose their recognition of Chinese culture.

The author uses the test volumes, interviews and questionnaires designed by the research group to investigate the mastery of Chinese cultural knowledge and the expression of English. The Chinese culture in the test paper includes two parts. The first ten questions test is a broad cultural content, involving the value of Chinese culture, customs, etiquette, etc .; after 20 questions test is a narrow cultural content, involving ancient Chinese modern history and literature, literature and art, philosophy and religion, science Technology, historical figures and other cultural knowledge. Questions are multiple choice questions, each question with four options, only one is correct. Insider and alternative answers are in Chinese. The way to examine the situation of Chinese cultural knowledge is to see whether the test can choose the correct answer to the question. The way to examine the situation of Chinese cultural knowledge in English is to see if the problem can be described in English and the chosen answer. If the test of all the two parts of the wrong answer, or any part of the wrong answer, that test the existence of aphasia, the former can be interpreted as the test of Chinese cultural knowledge and its English expression of double aphasia, which can be interpreted as test China Cultural knowledge aphasia, or Chinese cultural knowledge English expression aphasia. Interview 1 survey of teachers and students in English classroom teaching Chinese culture teaching situation, a total of 3 questions. Interview 2 used to investigate the subjects of Chinese culture curriculum settings, a total of 2 questions. The purpose of these two interviews is to examine the English education and teaching management behavior in our country. The main purpose is to see whether Chinese cultural knowledge and its English expression aphasia are related to these important teaching and management behaviors. The questionnaire was used to investigate the attitudes of the teachers and students to Chinese culture teaching. There were five questions, which were mainly used to provide some effective suggestions for Chinese culture teaching. 
Table 1 some effective suggestions for Chinese culture teaching

\begin{tabular}{|l|c|c|c|c|c|c|}
\hline & $\begin{array}{c}\text { Generalized } \\
\text { Cultural } \\
\text { Knowledge } \\
\text { Average }\end{array}$ & $\begin{array}{c}\text { Generalized } \\
\text { Cultural } \\
\text { Knowledge } \\
\text { English } \\
\text { Expression } \\
\text { Average }\end{array}$ & $\begin{array}{c}\text { Narrow } \\
\text { Cultural } \\
\text { Knowledge }\end{array}$ & $\begin{array}{c}\text { Narrow } \\
\text { Cultural } \\
\text { Knowledge } \\
\text { English } \\
\text { Expression } \\
\text { Average }\end{array}$ & $\begin{array}{c}\text { Chinese } \\
\text { Cultural } \\
\text { Knowledge } \\
\text { (Broad Sense } \\
\text { + Narrow } \\
\text { Sense) }\end{array}$ & $\begin{array}{c}\text { Chinese } \\
\text { Cultural } \\
\text { Knowledge } \\
\text { (Generalized } \\
\text { + Narrow) } \\
\text { English } \\
\text { Expression }\end{array}$ \\
\hline $\begin{array}{l}\text { English } \\
\text { Majors }\end{array}$ & 1233 & 879 & 3586 & 1745.6 & 4518 & 2643.5 \\
\hline $\begin{array}{l}\text { Non - English } \\
\text { Majors }\end{array}$ & 1813 & 1307 & 5050 & 2015 & 6863 & 3323 \\
\hline $\begin{array}{l}\text { English } \\
\text { Teacher }\end{array}$ & 537 & 554 & 1364 & 1425 & 1954 & 1900 \\
\hline
\end{tabular}

On the test of the knowledge sector, we can see that the general knowledge of Chinese culture knowledge of the situation are not as good as the narrow sense of Chinese culture to grasp the situation, the former are lower than the latter 10 or nearly 10 percentage points. English professional students in this part of the answer is only 65.3\% correct rate, rather than the English professional test answer the correct rate is less than the grid (57.6\%), the answer to the best English teachers the correct rate is only 69\% The This shows that all subjects generally on the nation's way of thinking, customs, beliefs and other cultural knowledge of learning, understanding is not enough. Although the test of the narrow sense of Chinese cultural knowledge test performance is better than the general Chinese cultural knowledge test results, but the part of the correct rate of answer is basically within the grid line. And the students' English expression is generally lower than the Chinese cultural knowledge test results and the narrow sense of Chinese culture in English performance is even more obvious, positive rate difference of nearly 40 percentage points.

On the whole, the average score of Chinese culture knowledge (71.73 / 65.35) was much higher than that of Chinese cultural knowledge (41.96 / 31.66), while the average score of Chinese culture knowledge (75.19) with its Chinese cultural knowledge English expression (73.13) basically flat. Judging from the positive rate of each test part of the test, the Chinese culture of the test and its English expression is far from satisfactory.

In terms of the test group, the best test results are English teachers, followed by English majors, the weakest non-English majors. The best explanation here may be due to the professional characteristics of the subject. Regardless of the performance of the test in the test, most of their knowledge of the reserves will not be obtained during college English education and this possibility can be derived from other studies in this study, such as the Chinese culture classes and English class An Investigation of Chinese Culture Teaching. As the professional characteristics of the test is not the same, usually the accumulation of knowledge content, category, the focus may not be the same, so that non-English professional test Chinese cultural knowledge and its English expression far behind the reasons for the English professional test It is here.

\section{The Causes of Chinese Cultural Aphasia in College English Education}

Chinese Culture Teaching Has Long Been Neglected. For the college English teaching, China's Ministry of Education has issued a document on the emphasis on language culture teaching, and most of the English teaching outline also made clear that Western culture should be held to learn and understand the attitude to understand. However, in the actual teaching, teachers are more to introduce Western culture, and textbooks are mainly focused on the Western customs and cultural, but seriously ignored the traditional Chinese culture of cognitive learning. For example, from the primary school to the middle school textbook content, are to reflect the British culture, which for learning English has its role in promoting, but students in the long-term Western cultural awareness which cannot use English to learn Chinese culture, under this teaching, students will gradually lose their interest in the mother tongue culture, for the Western culture is enthusiastic. 
Put Too Much Emphasis on the Importance of English Teaching. In English teaching, the reason why the "Chinese aphasia" phenomenon, in the final analysis, China's English teaching too much attention. Big school, small to the parents of students are too much to require students to English as a top priority, such as today's curriculum, the English discipline is the most educated subjects of all the longest course of study, and whether it is English of the students or job seekers, many require the need to have English reading and writing ability, so, in the subtle, English teaching has gradually become the master of the discipline. In contrast to our mother tongue teaching, its curriculum is limited to high school, and college language only for individual professional students to open. Therefore, too much emphasis on English teaching will only prematurely kill students in the cradle of learning the mother tongue, so that students increasingly feel that learning the mother tongue culture is not so important.

\section{The Strategies of Chinese Cultural Aphasia in College English Education}

Strengthen the Preparation of Teaching Materials. Most of the current English textbooks are mainly Western culture, and the content of Chinese culture is extremely lacking. Therefore, in order to reduce the phenomenon of "Chinese cultural aphasia", we should strengthen the English tutorial, not limited to the introduction of English culture, but the traditional Chinese culture into the English textbooks, so that students access to the mother tongue culture, and learn In the cross-cultural exchange in the free expression of Chinese cultural elements in English, at the same time, teachers can also make full use of network classroom teaching or on-site experience teaching, so that students can more intuitive understanding of Chinese culture on the English material, Students learn English at the same time, but also to enhance the understanding of Chinese traditional culture.

In the process of teaching the choice of teaching materials, on the one hand not only need to focus on the Sino-US cultural background of the relevant articles for analysis, but also should pay attention to some foreign writers to the traditional Chinese culture as the theme of the article, such as the history of China, Culture, economic development, etc., and these content into the textbook. The promotion and dissemination of culture not only to absorb some foreign culture, but also must be on the characteristics of China in English to express effectively, in order to carry forward the spread of Chinese culture. In general, in the teaching process, the teacher should be student-oriented, and to classroom practice as the main goal, and strive to create a language and culture combined teaching platform.

Reform Course Teaching Settings. In recent years, China has a significant reform in English four or six, for the examination of the subject to increase the traditional Chinese culture in the subject of translation, in the college entrance examination subjects also gradually reduce the proportion of English scores, and vice versa to improve the proportion of language scores. Therefore, as China's emphasis on the culture of the mother tongue, the major colleges and universities should also gradually begin to reform English teaching, such as college English courses can add the traditional Chinese culture and Western culture contrast. Students can learn from the knowledge of Chinese culture and fluent in English to express the Chinese culture, enhance the mother tongue at the same time enhance the students' national cultural identity

Cultivate the Chinese Culture Subject Consciousness. Learn English in order to be able to cross the cultural exchanges in the better spread of the Chinese culture of the world, therefore, should not only learn English is limited to listening, speaking, reading and writing and so on. College English teaching should clearly show the purpose of learning and the purpose of students to learn to improve students' awareness of the spread of Chinese culture, an objective perspective to learn English and mother tongue, learners not only to learn English should not ignore the status and role of mother tongue culture, In improving the cross-cultural communication ability through, to enhance the identity of the mother tongue culture, and promote the harmonious development of cultural exchanges between China and the West.

Cultural Consciousness. Cultural consciousness is living in a certain range of cultural history of the people, the culture will have a certain sense of self-knowledge, and the development of culture and the future have a certain understanding. In the process of learning English, we should first 
identify their own position, and the traditional Chinese culture and English combined with each other, which play a role in learning from each other, and the traditional Chinese culture and external promotion, to take the English innovation to Chinese culture to reflect the measures, and constantly cultivate college students on the Chinese culture heritage.

Teaching Methods. In the classroom teaching, we should make efforts to create a learning environment. In the process of classroom teaching, communicative activities can effectively provide a basis for learning people and this opportunity can make students in the classroom environment to learn the creative use of knowledge. Teachers must guide students in the process of learning, the relevant literary works, cultural background and social relations related to an effective analysis, so as to contrast the culture of China and the West.

\section{Conclusion}

"Chinese cultural aphasia" phenomenon is a major problem in the major colleges and universities, to solve this problem not only requires education reform, but also need to improve their own Chinese culture to cultivate and enhance the identity of the Chinese culture and mission. Only to allow learners to learn English and mother tongue culture combined can better be to the Chinese culture to the world, promote cross-cultural exchanges and development.

\section{References}

[1] Huifang Zhou: TESOL Matters, Vol. 2 (2001) No 26, p.2205

[2] Hongli Zhang: Journal of Distance Education, Vol. 5 (2012) No 27, p.124-127

[3] Qin Guo: English Teaching Forum, Vol. 1 (2006) No 33, p.78-80

[4] Jieming Liu: Guangxi Normal University, Vol. 3 (2007) No33, p.56-58

[5] Jia Xinzhang, Li Jingyuan. Modern Foreign Language, Vol. 6 (2014) No 53, p.80-81 